\title{
Analysis of the Key Financial Factors Affecting the Profitability of Enterprises in the Context of the Digitalization of the Economy
}

\author{
S. Romanova*, S. Maryanova, A. Naumov \\ Institute of Service and Business (branch) of DSTU in Shakhty, Shakhty, Russia \\ ${ }^{*}$ Corresponding author.Email: rromanova-sv@yandex.ru
}

\begin{abstract}
The scientific article is devoted to the research analysis of the influence of the key financial factors shaping the size of the enterprise profitability in the context of digital transformation of economy. The relevance of the study is due to the digitalization of business activities and markets which make management organizations take into account the impact of digital transformation on the financial condition and profitability of the business. The features of digitalization of commercial activities of enterprises in the economy of the Russian Federation are considered within the framework of the article. The main directions and technologies of digitalization, as well as the problems that hinder this process are described. The influence of the digitalization conditions of the economy on the process of creating key financial factors affecting the profitability of enterprises has been analyzed. In the conclusion of the article, the authors found out that the digitalization of the economy forms new directions for optimizing the costs of production activities and expanding the range of products and services at enterprises to create favorable conditions for financial stability, having a positive effect on the amount of business profit.
\end{abstract}

Keywords: digitalization, financial result, profit, financial stability, analysis, business model.

\section{INTRODUCTION}

The main condition for the success of the company's business activity is the generation of a positive cash flow, which forms the basis for making a profit from a commercial business. In turn, the formation of cash flow and profitability indicators of enterprises depends on the influence of a number of key financial factors, reflecting the degree of financial condition and stability of the organization. However, financial factors have their own basis, which creates one or another character of their formation. Today, such a basis for companies is the digital transformation observed in the international practice of public administration and the introduction of business activities.

Business digitalization, systems of enterprise and economy management is integral elements of modern economic activity, requiring accounting, analysis and active application, for predetermine the significance of the chosen research topic.

The purpose of this study is to analyze the level of digitalization of the economy as an auxiliary tool aimed at improving the efficiency of business activities and markets and to develop tools for assessing this impact. Based on the set goal, the following tasks are formed:

- to assess the dynamics of development and characterize the level of using digital technologies by Russian enterprises in the framework of strengthening their market positions;

- to denote the digital transformation processes of the business model of enterprises, affecting the key financial drivers and profitability;

- to clarify the relationship between the digitalization of the enterprise business model and financial resources;

- to analyze the impact of the digitalization conditions of the economy on forming the key financial factors affecting the profitability of enterprises;

- to study and substantiate the possibilities of practical application of key analyzing methods and tools of financial factors influence on the financial results of the organization; 
- to propose recommendations for improving management processes in the context of the economy digitalization.

\section{MATERIALS AND METHODS}

Digitalization in the enterprise management is the process of automating the organization business processes and informatization of the management system. The characteristic of such a process is that the model of the organization business processes is transformed into the form of digital data; the analysis and systematization of these data improve the management activities and increase the efficiency of decision-making by management [1].

The current stage of development of the national economy of the Russian Federation involves the following active processes, such as:

- the development of the state program «Digital Economy» and implementation of national projects within its framework;

- digital transformation of industries and markets;

- digitalization and automation of production and financial activities;

- digitalization and informatization of the enterprise management system;

- improving the products quality and increasing the complexity level of customers' needs, whose satisfaction is impossible without the use of innovations and new developments.

Digitalization in the Russian economy plays an important role, stimulating the economic development of domestic business [2]. In particular, this is reflected through indicators that show the dynamics of the contribution of digitalization to the formation of the country's gross domestic product (Figure 1)

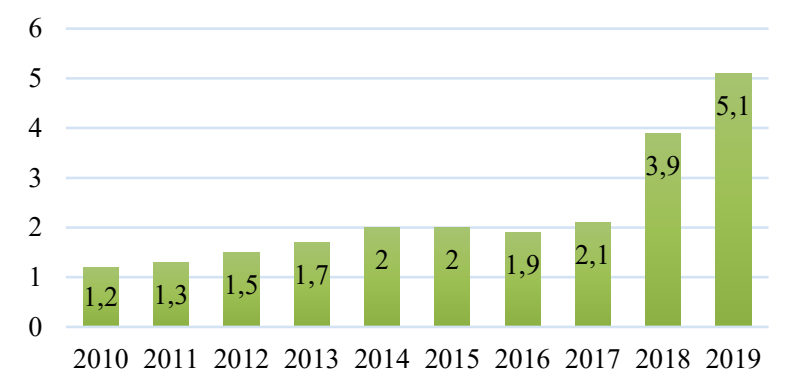

Figure 1 Dynamics of indicator of the digitalization contribution into the economic growth of Russia's GDP for the period 2010-2019, in\%

Thus, in the period for 2018-2019 at the beginning of implementing the first measures of the Government of the Russian Federation aimed at digitalizing the national economic system, a sharp increase in the contribution of this process to the country economic growth and changes in the volume of GDP can be noted.

This allows expecting a positive impact of digitalization on the profitability indicators of Russian enterprises, because the volume of GDP reflects the production volume, as the income and revenue depend on its size.

The influence of the conditions of the economy digitalization on the profitability of enterprises is done through a number of key financial factors; first of all, it occurs through the digital transformation of the organization business model and using digital technologies.

On the other hand, within the framework of the formation and development of digital technologies as the basis of enterprise management, the important role is played by the access availability to the financial resources base, as necessary condition for capital investments in implementing various innovative projects [2].

Therefore, the complete relationship between the two elements is noted:

- $\quad$ digitalization of the enterprise business model;

- the financial resources [3].

The process of digital business model transformation at enterprises, affecting key financial factors and profitability, can be classified into 3 key categories [4]:

1. Digitalization of customer service, which includes the digitalization procedure for deeper understanding of customers' needs and increase in revenue through increased product sales.

2. Digitalization of the operational process, which includes the automation of production and performance management using digital technologies.

3. Digitalization of business models and management systems, which includes the procedure of introducing new management and organizational technologies, as well as the integration of new digital business models that expand the enterprise directions.

As part of forming digitalization model, enterprises of the Russian economy use the following sets of innovations and digital technologies [5], as:

1. Cloud technologies allow relocating the database to digital environment giving access from anywhere in the world and desktop.

2. Application of artificial intelligence and machine learning technologies. These innovations allow using high-quality information recognition tools to 
expand digital capabilities in accounting, tax and management accounting.

3. Digital technologies of marketing activities. These include tools such as:

- SEO, thanks to which there is an increase in traffic and in the conversion of advertising offers;

- display advertising that allows maximizing audience reach and increases brand image and brand awareness;

- SMM, which is able for enterprises to spend minimal money costs for promotion and attracting live audience;

- marketing content allows gaining consumer confidence, increasing brand image and brand awareness, and has a high level of engagement with SEO.

4. Electronic document management system helps in optimization of document circulation and reduces labor and time costs for carrying out such operations.

However, in the modern economy of the Russian Federation, there are a lot of problems that hinder the development and active use of digital technologies by Russian enterprises in the framework of strengthening their market positions [6]. These include:

- the lack of desire among managers and owners of enterprises to implement innovations;

- the lack of financial resources, both internal and external sources, which are necessary for innovation;

- the lack of financial resources, both internal and external, that are necessary for innovation;

- the low efficiency of competition policy in Russia, due to it many industries, enterprises do not see the need to introduce innovations;

- the lack of prediction among the owners and managers of enterprises who want financial results now.

Despite a great number of problems, digitalization is becoming an important condition for the strategic and sustainable business development in Russian and foreign enterprises. This impact is observed through the formation of key financial factors generating cash flows and organization profits.

The commercial activity of each organization is to achieve a financial result, expressed in increased amount of the company profit. To ensure the efficiency of economic activities and production processes, it is necessary to competently manage financial resources.
The result of this procedure forms indicators that reflect the degree of financial stability at the enterprise.

At the same time, financial organization management is to take into account not only the internal characteristics of the production cycle, but also the analysis of external factors that can directly or indirectly affect the financial stability of the business. Thus, it is necessary for enterprise managers to conduct a study of environmental factors influencing the finance levels.

The most important aspect of financial stability management is the assessment and analysis of the financial performance of the organization, when studying internal and external financial factors affecting the profitability of enterprises [7].

When assessing the financial stability data of an enterprise, more than 200 different indicators can be taken into account, the main of which are presented below (Figure 2). They need to be divided into 4 main groups:

- liquidity indicators;

- $\quad$ indicators of the turnover of funds;

- $\quad$ indicators of profitability;

- market indicators.

\begin{tabular}{|c|c|}
\hline $\begin{array}{l}\text { Liquidity } \\
\text { indicators }\end{array}$ & $\begin{array}{c}\text { Current liquidity } \\
\text { - ratio quick ratio } \\
\text { - Absolute liquidity ratio } \\
\end{array}$ \\
\hline $\begin{array}{l}\text { Turnover } \\
\text { indicators }\end{array}$ & $\begin{array}{l}\cdot \text { Asset turnover } \\
\text { - Average debt repayment period } \\
\text { - Debt turnover } \\
\end{array}$ \\
\hline $\begin{array}{l}\text { Profitability } \\
\text { indicators }\end{array}$ & $\begin{array}{c}\text { - Profitability of working capital } \\
\text { - Return on assets } \\
\text { - Return on equity }\end{array}$ \\
\hline $\begin{array}{l}\text { Market } \\
\text { indicators }\end{array}$ & $\begin{array}{l}\cdot \text { Increase in share price } \\
\cdot \text { Dividend income } \\
\cdot \text { Company real value ratio }\end{array}$ \\
\hline
\end{tabular}

Figure 2 A set of indicators for assessing the financial stability of the company

There are a lot of methods for analyzing the financial stability of enterprises. Some of the most popular in Russian practice are Savitskaya's technique and Sheremet's technique.

Each of these methods is used for assessing the financial stability of companies and includes, first of all, the analysis of internal factors, namely the economic indicators of production, financial and investment activities [8].

To study the external factors affecting the financial stability of enterprises, as a rule, managers also use classical methods and tools that correlate with the analysis of the internal environment. However, it is necessary to take into account certain external factors of the Russian economy, which have a detrimental effect on the financial stability of domestic business [9]. 
So, the current difficulties and problems that act as external factors affecting the financial stability of companies are:

- the devaluation of the Russian ruble, which is associated with the negative impact of the oil market;

- the corona virus pandemic, which is a threat to the future development of the global and domestic economy due to a decline in production and investment activity;

- the growth of inflation, which affects the consumer ability of the population, which means that it is able to influence the internal indicators of sales and revenue of the company;

- tightening of the monetary policy of the Bank of Russia, which implies an increase in the level of interest rates on commercial lending and an increase in barriers to external financing.

At the same time, within the framework of analyzing the influence of these external financial factors on the profitability of enterprises, it is worth using the methods of strategic analysis.

For example, the most classic tool is SWOT analysis, which is based on the analysis of four areas, including the strengths, weaknesses, opportunities and threats of the company [10].

The disadvantages of using SWOT analysis in analyzing environmental factors are:

- the presence of subjectivity in determining the factors;

- the lack of adaptation to rapid economic conditions changing.

However, it has such advantages as ease of implementation and simplicity. This strategic analysis tool can be used by enterprises to assess external financial factors that indirectly affect the profitability of a company business [11].

Another popular example of studying external financial factors is PEST analysis, which is used to assess the external environment of an organization to identify factors that affect business profitability [12]

The advantages of the PEST analysis technique include:

- $\quad$ ease of implementation and use;

- $\quad$ the visibility of application.

The advantages of PEST analysis are its clarity, simplicity and applicability, which allow identifying opportunities for business development and the realization of competitive potential.
The disadvantages of this strategic analysis tool are such factors as restricting access to reliable information, as well as the fact that this analysis should be carried out on the ongoing basis, which means that it requires the following measures in strategic planning and enterprise management as continuous optimization of the development strategy [13]. However, the following urgent question arises: how do the key financial factors affect the profitability of enterprises in the context of digitalization?

We demonstrate the answer by using the example of Kazan Reinforced Concrete Plant LLC, which has faced two main problems lately:

1. The increase in costs and the size of the production cost.

2. The decrease in the volume of products demand and an increase in accounts receivable.

The total enterprise expenses for the last year amounted to 29.004 million rubles. When analyzing the structure of the product sales, it is worth noting that for LLC Kazan Reinforced Concrete Plant, the most important product is road slabs with the name DP-1. The cost of this product is 13,441 rubles, and the cost of its production is 11,299 rubles. Thus, the net income between the selling price and the cost of production of the road slab is - 2142 rubles.

However, a huge part of the enterprise's expenses is occupied by administrative expenses and logistics costs and sales of products to the final consumer.

It is due to this reason that the aggregate financial result of Kazan Reinforced Concrete Plant LLC has dropped to a negative zone and amounted to 21.643 million rubles in 2019 (Figure 3).

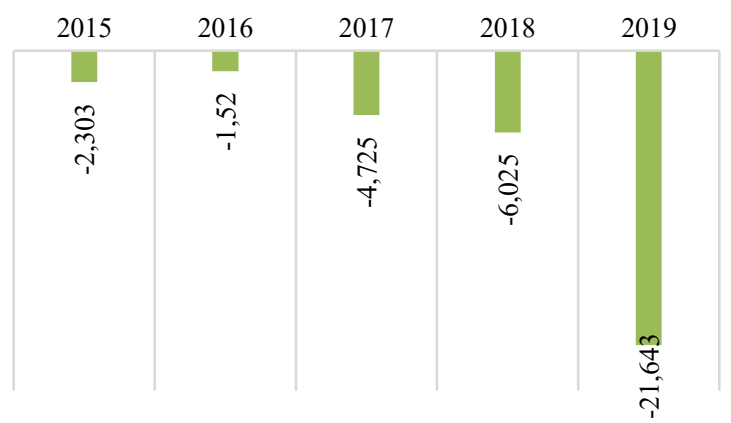

Figure 3 Dynamics of the aggregate financial result of Kazan Reinforced Concrete Plant LLC for the period 2015-2019, in million rubles.

Thus, two main problems (an increase in production costs and a drop in demand) led to the formation of a net loss in the business activity of the company Kazan Reinforced Concrete Plant LLC.

In order to optimize costs and increase the size of the company profitability, the management decided to 
improve the marketing strategy and pricing procedures using the latest digital technologies.

First, new methods of marketing research of the industrial market products were used by means of Hotjar and Survey Monkey technologies. These tools allow not only using question scripts, but also immediately analyzing the results obtained [14].

Secondly, Big Data technologies were used to improve the efficiency of marketing research and to ensure work with a large array of analytical data that helps increase the level of financial business stability [15].

As a result, these digital technologies allowed the management of Kazan Reinforced Concrete Plant LLC to achieve the following results:

- take the company out of the unprofitable zone and earn 64 thousand rubles of profit;

- to reduce the volume of accounts receivable from 11.307 million rubles to 3.337 million rubles;

- to increase the size of fixed assets of the enterprise from 11.387 million rubles to 15.684 million rubles, which is due to the modernization of production facilities in order to reduce the cost of industrial production and ensure production effect growth.

\section{RESULTS}

The results of the study suggest that the trends, processes and prospects of the digital transformation of the Russian economy form new directions for optimizing the production activities costs and expanding the range of products and services at enterprises, when it is possible to create favorable conditions for financial stability, having a positive effect on the amount of business profit. Nevertheless, in order to increase the level of financial business stability, it is necessary to constantly improve these processes by:

- developing the latest methods of marketing research, allowing, first of all, to analyze the results;

- practical application of technologies with the following characteristics, such as: maximum amount of information; decentralized way of storing information; semi-structured and unstructured data storage system; horizontal model of storing and processing information; weak interconnection of data and information.

The development of these areas is a significant prerequisite for improving management processes in modern economic conditions.

To optimize management processes, both in general, income and expenses, in particular, it is necessary, first of all, to organize complex work in the following areas:
- $\quad$ to ensure the digitalization of collecting, processing and analyzing larger array of data, as no one person is capable of;

- to increase the selection of information tools, since different types of materials can be used simultaneously, such as text, graphics, video, audio, etc;

- $\quad$ to form the possibilities of personalizing marketing proposals at the enterprise, since these technologies can analyze the information of individual target audiences, distinguishing it from all others;

- $\quad$ to assess the real level of customer satisfaction;

- to provide opportunities for assessing the conformity of the product quality or customer's service with consumer's expectations.

According to McKinsey, the digital economy in Russia is still only 4\% of GDP, in the United States about $10 \%$. In the UN rating of electronic governments of the world, Russia took 32nd place, in 2012 it was 59 th. Also, Russia rose from 34 th to 23 rd place in the EParticipation index - it shows the participation of citizens in government decision-making using IT. Russia is still lagging behind Europe and the United States in terms of digitalization, but is confidently following this course. Now is the time for businesses to get involved in the digital transformation process. If it still hasn't done it.

\section{CONCLUSIONS}

Summing up the results of the research analysis carried out within the framework of a scientific article, one can come to the following conclusions:

1. Analysis of key internal and external financial factors affecting the profitability of enterprises is a procedure for ensuring business financial stability, since within its framework the impact of certain triggers is assessed, and it is also possible to prevent possible risks.

2. The digital economy transformation affects enterprises from different sides: there is a digitalization of business models, automation of production activities, as the management system is being improved through the introduction of digital technologies.

3. The economy digitalization forms new directions for optimizing the production activities costs and expanding the range of products and services at enterprises, creating favorable conditions for financial stability, having a positive effect on the amount of business profit

4. Digitalization and digital transformation of the economy will have a positive effect on the business 
environment, which will enhance the beneficial effect of external financial factors on the growth of profitability at enterprises focused on the formation of an innovation-oriented development strategy.

\section{REFERENCES}

[1] Audrius Dzikevičius, Svetlana Šaranda. In: Business: Theory and Practice, 17(2) (2016) pp. 159-166.

[2] Tatiana Pogodina, Tatiana Muzhzhavleva, Natalya Udaltsova. In: Entrepreneurship and Sustainability, 7(3) (2020) pp. 1555-1564.

[3] Miroslav Švabovič, Romualdas Valkauskas. In: Business: Theory and Practice, 13(3) (2012) pp. 234-241.

[4] Daiva Tamulevičiene, Jonas Mackevičius, Informacijos Mokslai. 86 (2019) pp. 157-173.

[5] Jerzy Stadnicki, Andrii Terebukh. In: Management and Production Engineering Review, 11(4) (2021) pp. 25-33.

[6] Petr Novák, Boris Popesko. In: Economics and Sociology, 7(4) (2014) pp. 89-103.

[7] Svetlana Romanova, Tatiana Popova, Irina Slatvitskaya, Daria Mironova. In: Espacios, 38(33) (2017) p. 37.

[8] Arsen Tatuev, Georgiy Kutsuri, Sergey Shanin, Violetta Rokotyanskaya, Svetlana Romanova. In: Journal of Engineering and Applied Sciences, 12(8) (2017) pp. 2045-2053.

[9] Nadezhda Kapustina, Antonina Rjachovskaya, Dmitrii Rjachovskij, Liubov Gantseva. In: Journal of Reviews on Global Economics, 7(Special Issue) (2018) pp. 726-730.

[10] Oksana Moshchenko, Violetta Rokotyanskaya, Svetlana Romanova, Svetlana Maryanova, Valeriia Shchennikova. In: Revista San Gregorio, 27 (2018) pp. 187-193.

[11] Jonas Mackevičius, Romualdas Valkauskas. In: Business: Theory and Practice, 11(3) (2010) pp. 213-221.

[12] Novia Wijaya, Kashan Pirzada, Chelsea Fanady. In: Journal of Security and Sustainability, 9(4) (2020) pp. 1265-1273.

[13] Irina Marchenkova, Alla Udovikova, Natalia Lyakhova, Natalja Gordeeva. In: Humanities and Social Sciences Reviews, 7(5) (2019) pp. 932-940.

[14] Natalya Vinogradova, Alexander Popov. In: Entrepreneurship and Sustainability, 6(4) (2019) pp. $1798-1806$.
[15] Daiva Tamulevičienè, Manuela Tvaronavičienè, Jonas Mackevičius. In: Journal of International Studies, 13(4) (2020) pp. 128-142. 